\title{
Fat Grafting: Current Concept, Clinical Application, and Regenerative Potential, Part 1
}

Editors

LEE L.Q. PU

KOTARO YOSHIMURA

SYDNEY R. COLEMAN
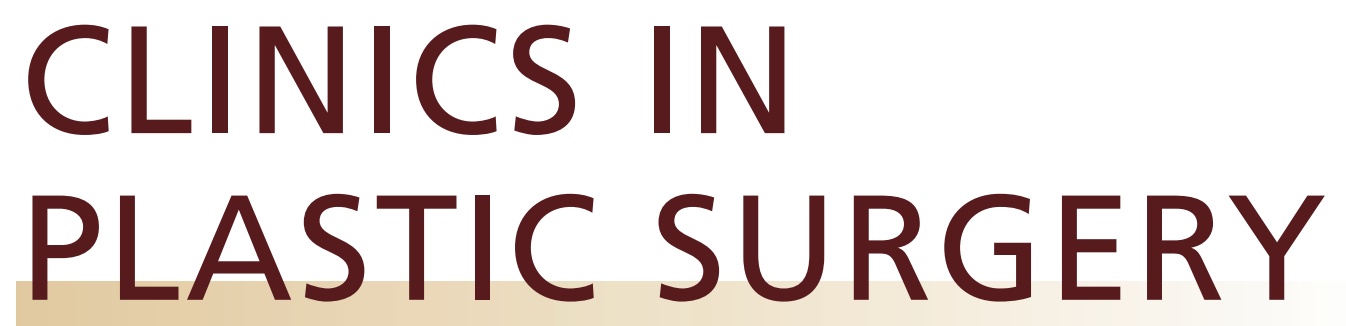

www.plasticsurgery.theclinics.com

April 2015 - Volume 42 - Number 2 